Halaman 23-36

\title{
Pengaruh Model Pembelajaran Inkuiri Terbimbing Berbasis Joyful Learning (Interjoy) terhadap Keterampilan Proses Sains Siswa Kelas X SMA Negeri 2 Surakarta Tahun Pelajaran 2012/2013
}

\author{
The Influence Of Guided Inquiry Based Joyful Learning (Interjoy) \\ Learning ModelsToward Science Process Skills Of X Grade Students At \\ SMA Negeri 2 Surakarta In Academic Year 2012/2013
}

\author{
Alfian Chrisna Aji ${ }^{a}$, Slamet Santosa ${ }^{b}$, Riezky Maya Probosari ${ }^{c}$ \\ ${ }^{a}$ Pendidikan Biologi FKIP UNS, Email: alfianchrisnaaji@yahoo.com \\ ${ }^{\mathrm{b}}$ Pendidikan Biologi FKIP UNS, Email: slametsantosa_bio@yahoo.co.id \\ ${ }^{\mathrm{c}}$ Pendidikan Biologi FKIP UNS, Email: riezkymp@ gmail.com
}

Diterima 23 Juli 2013, disetujui 20 Desember 2013

\begin{abstract}
The aim of this research is to ascertain the influence of guided inquiry based joyful learning (interjoy) learning models toward science process skills of $\mathrm{X}$ grade students at SMA Negeri 2 Surakarta in academic year 2012/2013. This research was quasi experiment research which used posttest only nonequivalent control group design. This research applied guided inquiry based joyful learning (interjoy) learning models in experimental group and direct instruction learning models in control group. The population of this research was all of $X$ grade students at SMA Negeri 2 Surakarta in academic year 2012/2013. Sampling techniques used cluster sampling that choosed X.10 as experiment group and X.8 as control group. Data was collected using KPS test, observation sheet, and document. The hypotheses analyzed by t-test. This research concluded that application of guided inquiry based joyful learning (interjoy) learning models has real influential toward science process skills of X grade students at SMA Negeri 2 Surakarta.
\end{abstract}

Key Words: guided inquiry based joyful learning (interjoy) learning models, science process skills

\section{Pendahuluan}

Pendidikan merupakan suatu usaha yang dilakukan secara sengaja dan terencana untuk dapat membantu mengembangkan potensi di dalam diri manusia agar dapat berguna bagi kepentingan hidupnya, baik sebagai makhluk pribadi (individu) maupun makhluk sosial sebagai anggota masyarakat. Upaya meperoleh pendidikan setidak-tidaknya dengan melalui proses pembelajaran. Pelaksanaan proses pembelajaran sangat mempengaruhi mutu pendidikan di suatu negara Biologi sebagai bagian dari sains memiliki peranan yang sangat penting di dalam peningkatan mutu pendidikan.

Hakikat pembelajaran biologi sebagai bagian dari sains tidak lepas dari kegiatan minds on, hands on, dan hearts on, yaitu siswa atau peserta didik harus dapat melakukan kegiatan yang mampu mengasah keterampilan berpikir, praktek, dan berbudi pekerti yang luhur. Ketiga keterampilan tersebut, siswa diharapkan dapat aktif dalam kegiatan berpikir dan berproses untuk mengasah keterampilan 
sains sehingga siswa dapat menemukan konsep-konsep baru dari kegiatan belajar mereka serta berkarakter kuat dalam kehidupan sosialnya.

Pujiati (2008) menyatakan bahwa kurikulum KBK yang telah diberlakukan secara nasional sejak tahun pelajaran 2004/2005, masih berorientasi pada pencapaian hasil akhir atau produk yang dapat dijabarkan berupa kemampuan yang dapat diperagakan atau kompetensi siswa. Hasil belajar siswa biasanya diukur oleh guru dengan menentukan batas kelulusan yaitu $75 \%$ untuk menguasai bahan ajar atau sumber belajar.

Kenyataan di lapangan menunjukkan bahwa pembelajaran masih berorientasi pada hasil belajar atau produk, suasana kelas yang kurang kondusif karena proses pembelajaran didominasi oleh guru. Khusus mata pelajaran biologi sebagai bagian dari sains, selain berorientasi pada hasil pembelajaran seharusnya juga berorientasi pada proses, yaitu keterampilan proses sains (KPS). Rustaman (2005) menyatakan bahwa KPS sangat penting untuk dilaksanakan dan dikembangkan melalui kegiatan pembelajaran sebagai pengalaman langsung, pengalaman belajar, dan disadari pada saat kegiatan berlangsung. KPS dalam pembelajaran biologi dapat memfasilitasi siswa untuk mencapai pembelajaran sains dan mendorong siswa untuk menemukan sendiri konsep pengetahuan, fakta serta menumbuh-kembangkan sikap dan nilai yang dituntut.

Terkait dengan strategi belajar mengajar, pengembangan KPS memerlukan suatu kegiatan pembelajaran yang mendukung. Salah satu hal yang penting dalam mempengaruhi kegiatan pembelajaran adalah pendekatan yang diterapkan guru ketika mengajar. Penerapan suatu pendekatan yang mampu mengubah minat siswa terhadap pembelajaran biologi ditinjau dari karakteristik pembelajaran biologi yang bersifat abstrak dan teoritis sangat diperlukan. Penerapan pendekatan pembelajaran yang variatif dan sesuai dengan karakteristik siswa ini akan menghindarkan dari rasa jenuh, tercipta suasana belajar yang menyenangkan dan nyaman.

Salah satu alternatif pendekatan pembelajaran yang diharapkan dapat meningkatkan keterampilan proses sains siswa serta menciptakan kondisi belajar yang menyenangkan, tanpa beban, dan aktif melibatkan siswa adalah Joyful Learning atau pembelajaran menyenangkan. Wei et al. (2011) menyatakan bahwa Joyful Learning adalah pembelajaran yang membuat anak didik tidak takut salah, ditertawakan, diremehkan, tertekan, tetapi sebaliknya 
anak didik berani berbuat dan mencoba, bertanya, mengemukakan pendapat atau gagasan, dan mempertanyakan gagasan orang lain serta dalam suasana yang menyenangkan. Suasana pembelajaran yang menyenangkan diharapkan dapat meningkatkan kecerdasan dan merupakan cara belajar yang efektif untuk meningkatkan penguasaan dan pemahaman materi (Rachmawati, 2012).

Pembelajaran biologi, penguasaan konsep dapat lebih dioptimalkan jika siswa diberikan kesempatan untuk membangun sebuah konsep melalui pendekatan KPS. Berdasarkan hal tersebut, joyful learning dapat dikatakan tidak mencukupi karena joyful learning tidak berbasis metode ilmiah. Joyful Learning dapat dioptimalkan apabila didukung dengan pembelajaran yang berbasis metode ilmiah, misalnya model pembelajaran inkuiri terbimbing (Guided Inquiry).

Inkuiri terbimbing adalah salah satu model pembelajaran yang sangat menekankan pada penemuan konsep dalam pembelajaran biologi melalui KPS. Guru berperan sebagai pembimbing utama yang membimbing siswa untuk melakukan kegiatan pembelajaran dengan memberi siswa berupa permasalahan awal kemudian mengarahkan pada suatu diskusi. Trianto (2007) menyatakan pembelajaran inkuiri terbimbing mempunyai tahapan: penyajian masalah, mengajukan hipotesis, merancang percobaan, melakukan percobaan, menganalisis data, dan menarik kesimpulan. Umumnya siswa masih mengalami kesulitan pada penerapan inkuiri terbimbing dan suasana pembelajaran masih tegang karena siswa dituntut selalu berkonsentrasi.

Penerapan model pembelajaran Inkuiri Terbimbing berbasis Joyful Learning (Interjoy) diharapkan dapat mengembangkan KPS siswa karena berkaitan dengan keterampilan-keterampilan yang dipelajari siswa sehingga tahap pembelajaran di dalam Suasana pembelajaran Interjoy yang dikembangkan dengan metode ilmiah dapat menyenangkan dan melatih KPS siswa.

Penelitian ini bertujuan untuk mengetahui pengaruh penerapan model pembelajaran Interjoy terhadap KPS siswa kelas X SMA Negeri 2 Surakarta tahun pelajaran 2012/2013.

\section{Metode Penelitian}

Penelitian dilaksanakan di SMA Negeri 2 Surakarta pada semester genap tahun pelajaran 2012/2013. Penelitian ini termasuk kuasi eksperimen dengan pendekatan kuantitatif. Desain penelitian adalah Posttest Only Nonequivalent Control Group Design dengan menggunakan kelompok eksperimen (penerapan model 
pembelajaran Interjoy) dan kelompok kontrol (penerapan model pembelajaran direct instruction).

Populasi dalam penelitian ini adalah seluruh siswa kelas X SMA Negeri 2 Surakarta. Teknik pengambilan sampel dengan cluster sampling. Hasil pemilihan sampel menetapkan kelas X.10 dengan siswa sebanyak 32 orang sebagai kelompok eksperimen yang menerapkan model pembelajaran Interjoy dan kelas X.8 dengan siswa sebanyak 32 orang sebagai kelompok kontrol yang menerapkan model pembelajaran direct instruction.

Variabel bebasnya berupa model pembelajaran Interjoy, sedangkan variabel terikatnya adalah keterampilan proses sains yang meliputi aspek mengamati, mengelompokkan, merumuskan hipotesis, merencanakan percobaan, menggunakan alat dan bahan, mengkomunikasikan, dan menarik kesimpulan. Teknik pengumpulan data yang digunakan dalam penelitian ini adalah dokumentasi, tes, dan observasi. Dokumentasi pada penelitian ini berupa dokumen hasil belajar biologi yang diolah selama satu semester dengan nilai asli sebagai bahan acuannya yang digunakan untuk mengetahui keseimbangan kemampuan awal siswa berdasarkan nilai hasil belajar biologi pada populasi penelitian. Metode tes digunakan untuk mengambil data KPS siswa. Metode observasi dalam penelitian ini digunakan untuk mengukur hasil belajar ranah psikomotorik, ranah afektif dan keterlaksanaan rancangan pembelajaran.

Tes uji coba instrumen penelitian dilakukan untuk mengetahui validitas produk moment, dan reliabilitas soal tes KPS. Selain validasi produk moment, instrumen juga divalidasi konstruk oleh ahli.

Analisis data penelitian dengan menggunakan uji $t$. Sebelum analisis data, dilakukan uji normalitas menggunakan uji Liliefors dan uji homogenitas dengan uji Levene's yang dibantu program SPSS 16.

\section{Hasil dan Pembahasan}

Hasil uji hipotesis pengaruh penerapan model pembelajaran Interjoy terhadap KPS siswa kelas X SMA Negeri 2 Surakarta disajikan pada Tabel 1.

Tabel 1. Hasil Uji Hipotesis Pengaruh Interjoy Terhadap KPS

\begin{tabular}{cccccc}
\hline $\begin{array}{c}\text { Uji } \\
\mathbf{T}\end{array}$ & $\mathbf{t}$ & df & Sig. & $\mathbf{t}_{(\mathbf{0 . 0 5}, \mathbf{6 2})}$ & Keterangan \\
\hline KPS & 6.197 & 62 & 0.00 & 1.99897 & $\begin{array}{l}\mathrm{t}_{\text {hitung }}>\mathrm{t}_{(\alpha, \mathrm{df})} \\
\text { Sig. }<0.050\end{array}$ \\
\hline
\end{tabular}

Tabel 1. menunjukkan bahwa nilai Sig. $<0.050$ dan nilai $t_{\text {hitung }}>\mathrm{t}_{(\alpha, \text { df })}$ sehingga $\mathrm{H}_{0}$ ditolak. Hal ini berarti penerapan model pembelajaran Interjoy berpengaruh nyata terhadap KPS siswa. 
Pengaruh tersebut bersifat positif karena didukung secara deskriptif yaitu dari data nilai rata-rata KPS sebesar 76,583 untuk siswa kelompok eksperimen. Sedangkan untuk kelompok kontrol memperoleh nilai rata-rata KPS sebesar 62,943.

KPS siswa di kelompok eksperimen yang menggunakan model pembelajaran Interjoy dalam pembelajaran lebih tinggi dibandingkan dengan kelompok kontrol yang menggunakan model pembelajaran direct instruction.

Model pembelajaran Interjoy adalah usaha inovasi dalam pembelajaran biologi. Pengertian model pembelajaran Interjoy mengacu pada perpaduan aspek dalam joyful learning dengan sintaks model pembelajaran inkuiri terbimbing. Pemaduan ini akan menghasilkan sintaks pembelajaran baru. Filosofi dasar yang melandasi pemaduan sintaks tersebut adalah pembelajaran sains akan lebih bermakna jika siswa bekerja inkuiri terbimbing dalam suasana pembelajaran menyenangkan. Asmani (2011) menyatakan bahwa pembelajaran joyful learning mengharapkan guru memantau kegiatan, memberi umpan balik, mengajukan pertanyaan, mempertanyakan gagasan, menciptakan pembelajaran yang menarik, meningkatkan motivasi dan membuat siswa tidak takut mencoba. Proses pembelajaran pada kelas X.10 sebagai kelompok eksperimen menunjukkan bahwa siswa sangat antusias selama kegiatan pembelajaran berlangsung. Hal ini terlihat pada saat guru melaksanakan langkah-langkah pembelajaran yang mendorong siswa untuk membangun sendiri pengetahuannya yang dilaksanakan dalam suasana yang menyenangkan pada materi konsep keanekaragaman hayati.

Tahap pertama inkuiri terbimbing (penyajian masalah awal) yang dipadukan dengan aspek joyful learning (pengalaman dan interaksi). Tahap pertama ini guru mempersiapkan obyek pengamatan asli berupa 3 ekor ikan cupang (Betta splendes) pada pertemuan pertama dan 3 tanaman famili poaceae yaitu Cynodon dactylon, Eleusine indica, dan Andropogon aciculatus pada pertemuan kedua untuk mengidentifikasi keanekaragaman tingkat gen dan spesies. Pengamatan terhadap keanekaragaman tingkat ekosistem, guru menampilkan 3 macam video, yaitu video hutan hujan tropis, padang rumput, dan gurun pada pertemuan ketiga. Melalui kegiatan pengamatan siswa lebih tertarik dalam berinkuiri dan berdiskusi dalam kelompok. Mereka mendiskusikan penyebab keanekaragaman, komponen penyusun, dan membuat suatu rumusan masalah. Tahap ini melatihkan KPS siswa, yaitu mengamati dan siswa mendapat pengalaman belajar langsung 
dengan kegiatan observasi. Amri dan Ahmadi (2010) menyatakan bahwa karakteristik inkuiri terbimbing yaitu pembelajaran yang mengembangkan kemampuan berpikir siswa melalui observasi spesifik sehingga mampu membuat inferensi. Kegiatan pengamatan, diskusi, dan merumuskan masalah siswa dibimbing oleh guru yang selalu memberi motivasi, pertanyaan yang membangun pengetahuan siswa, selalu berinteraksi aktif dengan siswa serta pemutaran musik instrumental yang pelan membuat siswa merasa nyaman.

Metode diskusi kelompok dalam belajar dapat memberikan kesempatan untuk siswa saling berinteraksi untuk mengembangkan pemahaman mereka terhadap konsep-konsep. Slavin (2008) menyatakan bahwa dengan berinteraksi, siswa termotivasi, mengajukan pendapat masing-masing, dan memunculkan nilainilai sosialnya. Yunianto (2008) menyatakan bahwa diskusi kelompok dapat mengembangkan tingkat pemahaman siswa karena dapat membawa siswa menggunakan konsep yang mereka pelajari dan mengubahnya menjadi bentuk ekspresi yang menyenangkan. Yustika (2011) menyimpulkan bahwa penerapan tutor sebaya pada inkuiri terbimbing berpengaruh terhadap peningkatan KPS siswa.
Penggunaan musik instrumental pada saat diskusi membuat siswa lebih tertarik terhadap pembelajaran. Penggunaan musik dapat merangsang pikiran, memperbaiki konsentrasi dan ingatan (meningkatkan aspek kognitif), selain itu juga dapat menyeimbangkan otak kanan dan kiri yang berarti menyeimbangkan perkembangan aspek intelektual dan emosional (Masnun dan Sudarman, 2010). Russel (2012) menyatakan bahwa musik memiliki kualitas unik dalam menyatu-padukan elemen emosional, kognitif, dan psikomotorik yang dapat mengaktifkan dan mensinkronkan aktifitas otak. Pemutaran musik instrumental yang pelan membantu untuk mengatur rentang perhatian yang singkat, natural, dan sifat dasar kinestik.

Tahap kedua inkuiri terbimbing (merumuskan hipotesis) yang dipadukan dengan aspek joyful learning (pengalaman dan interaksi). Pada tahap ini guru membimbing siswa untuk membuat rumusan hipotesis berdasarkan rumusan masalah yang telah dibuat. Siswa mempunyai pengalaman membuat rumusan masalah sehingga dengan membuat hipotesis dapat mengungkapkan cara melakukan pemecahan masalah (Rustaman, 2005). Guru memberikan kesempatan kepada siswa untuk bertanya tentang hubungan rumusan masalah dengan merumuskan hipotesis. Hal ini 
sejalan dengan hasil penelitian Carol (2007) yang menyatakan bahwa salah satu karakteristik strategi guided inquiry adalah siswa dapat mengembangkan rangkaian berfikir yang membutuhkan proses mendalam yang akan membawa sebuah pemahaman melalui bimbingan rangkaian berpikir ke arah yang lebih tinggi. Proses tersebut memerlukan waktu dan motivasi yang dibangun oleh berbagai pertanyaan mengenai objek yang diamati.

Tahap ketiga inkuiri terbimbing (merancang percobaan) yang dipadukan dengan aspek joyful learning (pengalaman dan interaksi). Pada tahap ini guru membimbing siswa untuk merancang percobaan pengamatan keanekaragaman hayati sesuai dengan petunjuk di lembar kerja siswa (LKS) yang meliputi pemilihan alat dan bahan serta cara kerja praktikum. Siswa memperoleh pengalaman dalam merancang percobaan pengamatan keanekaragaman hayati dengan bimbingan guru karena di sini siswa juga belajar cara menentukan untuk mengolah data sehingga nantinya dapat ditarik kesimpulan.

Tahap keempat inkuiri terbimbing (melaksanakan percobaan) dipadukan dengan aspek joyful learning (pengalaman dan interaksi). Pada tahap ini guru membimbing siswa dalam mengerjakan percobaan untuk mengamati obyek asli berupa 3 ekor ikan cupang (Betta splendes) pada pertemuan pertama dan 3 tanaman famili poaceae yaitu Cynodon dactylon, Eleusine indica, dan Andropogon aciculatus pada pertemuan kedua. Pengamatan terhadap keanekaragaman tingkat ekosistem, guru menampilkan 3 macam video, yaitu video hutan hujan tropis, padang rumput, dan gurun pada pertemuan ketiga. Siswa yang melaksanakan praktikum juga dapat mengaktifkan inderanya dengan cara mengamati keanekaragaman tingkat gen, spesies maupun ekosistem melalui masing-masing obyek pengamatan. Pengalaman ini bertujuan agar siswa dapat belajar secara mandiri yang meliputi eksperimen, pengamatan, percobaan, penyelidikan, dan wawancara secara langsung bagi siswa sangat diperlukan karena dapat mengaktifkan semua inderanya (Rusman, 2011). KPS yang diukur pada tahap ini adalah menggunakan alat dan bahan karena dalam melaksanakan percobaan pengamatan keanekaragaman hayati terlihat bagaimana siswa mampu menggunakan alat dan bahan sesuai dengan urutan langkah dan fungsinya serta mengukur keterampilan psikomotorik yang diukur melalui lembar observasi.

Tahap kelima inkuiri terbimbing (menganalisis data percobaan) dipadukan 
dengan aspek joyful learning (interaksi dan komunikasi). Pada tahap ini guru membimbing siswa dalam menganalisis data hasil percobaan. KPS yang diukur adalah mengelompokkan dan mengkomunikasikan. Siswa dapat mengelompokkan data percobaan yang meliputi persamaan dan perbedaan dari obyek pengamatan yang telah diamati. Guru memberi pertanyaan yang memotivasi siswa tentang apa saja yang telah diamati siswa. Pengetahuan siswa dibangun melalui pertanyaan-pertanyaan yang tersedia di dalam LKS. Runtutan aktifitas dan pertanyaan yang tercantum di dalam (LKS) sangat menunjang kegiatan inkuiri dan diskusi kelompok. LKS sangat penting dalam melatihkan KPS siswa sehingga nilai yang diperoleh juga tinggi. Hal ini sependapat dengan penelitian Ardiyanti (2011) yang menunjukkan bahwa penggunaan LKS terbuka dapat meningkatkan KPS siswa. Peningkatan KPS disebabkan karena siswa dirangsang dengan berbagai pertanyaan yang tercantum di LKS. Pertanyaan dapat melatih KPS siswa dalam proses memecahkan masalah dengan cara melaksanakan percobaan. Siswa perwakilan kelompok maju ke depan kelas untuk mempresentasikan hasil diskusi dan data percobaan yang didapatkan. Tahap ini juga dapat mengukur keterampilan sosial siswa.
Tahap keenam inkuiri terbimbing (menarik kesimpulan) dipadukan dengan aspek joyful learning (interaksi dan refleksi). Tahap ini guru membimbing siswa untuk mengulas kembali materi dan menyimpulkan hasil diskusi pada pertemuan hari ini. Guru memberi pertanyaan yang memotivasi siswa untuk mengingat kembali materi yang telah dipelajari sehingga siswa juga dapat menyampaikan gagasan dan pemahamannya tanpa rasa takut untuk salah. Refleksi digunakan agar terdapat perbaikan gagasan atau makna yang telah dikeluarkan oleh anak agar tidak mengulangi kesalahannya. Refleksi juga dapat dijadikan sebagai wahana evaluasi dari strategi yang telah diterapkan dan didapatkan hasilnya, sehingga kelebihan suatu pembelajaran dapat diketahui. Tahap refleksi digunakan oleh guru untuk melihat seberapa paham siswa dalam menerima pembelajaran. KPS yang dapat diukur pada tahap ini adalah menarik kesimpulan. Tahap ini melatih siswa untuk dapat menarik kesimpulan yang benar berdasarkan tujuan dan hasil percobaan pengamatan tingkat keanekaragaman hayati. Berdasarkan pengamatan di kelas, semua kelompok dapat menarik kesimpulan dengan benar sesuai dengan petunjuk guru.

Model pembelajaran Interjoy dalam penelitian ini dapat mengakomo- 
dasi siswa dengan gaya belajar visual dengan tulisan dan slide pembelajaran yang jelas yang dilengkapi dengan gambar-gambar yang menarik, LKS yang disertai gambar untuk memberikan kesan dalam ingatan bagi siswa, dan mengamati objek asli. DePorter dan Hernacki (2011) menyatakan bahwa langkahlangkah tersebut karena siswa dengan gaya belajar visual lebih mudah menyerap informasi melalui apa yang dilihatnya. Siswa dengan gaya belajar auditori dan kecerdasan musikal diakomodasi dengan memberikan penjelasan dengan intonasi yang jelas dan memainkan irama suara, selain itu guru juga memberikan penekanan irama pada beberapa kalimat penting yang digunakan untuk mengingat konsep serta memainkan musik instrumental secara pelan yang dapat membangkitkan semangat siswa dan kenyamanan pada saat berdikusi. Siswa dengan gaya belajar kinestetik diakomodasi dengan diskusi berkelompok dan melakukan percobaan agar mereka bisa selalu berinteraksi dengan teman-temannya serta melakukan suatu kerja nyata yang berhubungan dengan konsep yang dimilikinya.

KPS mencakup tiga ranah keterampilan siswa yang dapat mendukung pembelajaran biologi. Rustaman (2005) mengemukakan ketiga keterampilan tersebut adalah keterampilan intelektual, keterampilan psikomotorik, dan keterampilan sosial. Model pembelajaran Interjoy mencakup ketiga ranah keterampilan tersebut diantaranya keterampilan intelektual siswa dilatih dan dibimbing oleh guru dalam merumuskan masalah, membuat hipotesis maupun merencanakan percobaan. Keterampilan psikomotorik dapat diterapkan siswa pada saat melaksanakan percobaan meliputi menggunakan alat dan bahan yang benar waktu percobaan pengamatan keanekaragaman hayati. Keterampilan sosial diterapkan siswa ketika berdiskusi, berinteraksi dengan guru, menyampaikan gagasan maupun pertanyaan serta berinteraksi dengan teman ketika memecahkan masalah.

Penerapan model pembelajaran Interjoy dikontrol melalui lembar observasi keterlaksanaan sintaks model pembelajaran Interjoy. Hasilnya menunjukkan bahwa semua sintaks model pembelajaran Interjoy telah terpenuhi. Hal ini dapat diartikan bahwa guru dapat melaksanakan pembelajaran sesuai dengan unsur-unsur yang terdapat dalam model pembelajaran Interjoy sehingga model pembelajaran Interjoy terlaksana dengan baik dan lancar.

Pembelajaran dengan Interjoy pada kelompok eksperimen di kelas X.10 sangat berbeda dengan proses pembelajaran di kelas X.8 sebagai kelompok 
kontrol yang menerapkan model pembelajaran yang biasa dilakukan guru di kelas tersebut dalam mengajar, yaitu model pembelajaran direct instruction (model pengajaran langsung) dengan metode ceramah, diskusi, dan tanya jawab pada materi keanekaragaman hayati. Pembelajaran di kelas kontrol lebih didominasi guru sehingga lebih bersifat teacher centered sehingga siswa cenderung pasif dan tidak menikmati proses pembelajaran. Guru menjelaskan sebagian besar materi keanekaragaman hayati dengan ceramah, menampilkan gambar contoh keanekaragaman hayati siswa berdiskusi secara berkelompok untuk mengerjakan lembar kerja siswa dan disertai pertanyaan-pertanyaan kepada siswa, kemudian siswa menjawab pertanyaan yang diajukan guru. Namun, hanya sedikit siswa yang antusias menjawab pertanyaan guru. Perhatian dan minat siswa di dalam proses pembelajaran juga kurang, banyak siswa yang cenderung berbicara sendiri, melamun, tidak memperhatikan pelajaran. Suasana pembelajaran menjadi kurang bersemangat, monoton, dan menjenuhkan. Pada saat diskusi dan presentasi perwakilan kelompok, siswa cenderung kurang antusias karena suasana dan motivasi belajar yang kurang bahkan melakukan aktifitas yang tidak berkaitan dengan pembelajaran. Model pembelajaran direct instruction dengan metode ceramah, diskusi, dan tanya jawab juga kurang mengakomodasi dalam membangun pengetahuan siswa karena tidak berbasis metode ilmiah sehingga KPS siswa kelompok kontrol lebih rendah daripada kelompok eksperimen.

Hasil pengamatan dalam model pembelajaran Interjoy menunjukkan siswa berpartisipasi aktif di dalam proses pembelajaran. Siswa diberi kebebasan dalam mengajukan pertanyaan maupun pendapat tanpa rasa takut, membangun pengetahuan melalui kegiatan inkuiri yang dibimbing oleh guru. Tahap-tahap dalam Interjoy menuntut siswa selalu aktif membaca, bertanya, memahami, mendiskusikan masalah, membangun pengetahuan karena suasana pembelajaran berlangsung menyenangkan dan berpengaruh terhadap KPS siswa.

Referensi hasil penelitian yang menjelaskan pengaruh model pembelajaran interjoy terhadap KPS siswa belum ada, namun terdapat beberapa penelitian yang mendukung seperti Prayitno (2011) yang menyatakan bahwa inkuiri terbimbing berpotensi meningkatkan keterampilan proses sains. Langkah kegiatan pembelajaran inkuiri terbimbing dikembangkan dengan metode ilmiah. Kerja metode ilmiah menuntut siswa menjalani proses seperti ilmuwan 
menemukan ilmu sehingga inkuiri terbimbing berpotensi meningkatkan keterampilan proses sains. Hal ini didukung oleh pendapat Zehra dan Nermin (2009) yang menyatakan bahwa model pembelajaran inkuiri terbimbing mampu meningkatkan keterampilan proses sains siswa melalui serangkaian penyelidikan ilmiah. Rachmawati (2012) menyatakan bahwa suasana pembelajaran yang menyenangkan dapat meningkatkan kecerdasan dan merupakan cara belajar yang efektif untuk meningkatkan penguasaan dan pemahaman materi pelajaran. Pendekatan joyful learning layak digunakan dalam proses pembelajaran. Yunianto (2008) juga menyimpulkan bahwa pembelajaran berbasis joyful learning dapat meningkatkan kualitas proses pembelajaran.

KPS yang dilatihkan pada model pembelajaran Interjoy diantaranya seperti mengamati, mengelompokkan, merumuskan hipotesis, merencanakan percobaan, menggunakan alat dan bahan, mengkomunikasikan, dan menarik kesimpulan. Rangkuman nilai rata-rata tiap aspek KPS pada kelompok kontrol dan eksperimen disajikan pada Tabel 2.

Tabel 2. Nilai Rata-Rata Tiap Aspek KPS Kelompok Kontrol Dan Eksperimen

\begin{tabular}{lcc}
\multicolumn{1}{c}{ Aspek KPS } & $\begin{array}{c}\text { Kelas } \\
\text { Kontrol }\end{array}$ & $\begin{array}{c}\text { Kelas } \\
\text { Eksperimen }\end{array}$ \\
\hline Mengamati & 74,22 & 83,8 \\
Mengelompokkan & 56,38 & 76
\end{tabular}

\begin{tabular}{lcc}
$\begin{array}{l}\text { Merumuskan } \\
\text { hipotesis }\end{array}$ & 55,08 & 83,3 \\
$\begin{array}{l}\text { Merencanakan } \\
\text { percobaan }\end{array}$ & 53,91 & 76,46 \\
$\begin{array}{l}\text { Menggunakan alat } \\
\text { dan bahan }\end{array}$ & 54,3 & 82 \\
$\begin{array}{l}\text { Mengkomunikasi- } \\
\text { kan }\end{array}$ & 71,88 & 74,6 \\
$\begin{array}{l}\text { Menarik } \\
\text { kesimpulan }\end{array}$ & 71,09 & 71,3 \\
\hline
\end{tabular}

Tabel 2 terlihat bahwa nilai aspek KPS yang tertinggi pada kelompok kontrol adalah aspek mengamati $(74,22)$. Proses mengamati pada kelompok kontrol terlihat saat siswa membandingkan berbagai gambar contoh tingkat keanekaragaman hayati pada slide powerpoint yang ditampilkan guru. Nilai rata-rata aspek mengamati pada kelompok kontrol paling tinggi disebabkan karena membuat siswa terlibat secara langsung sehingga siswa sangat tertarik untuk melakukan kegiatan mengamati. Nilai rata-rata aspek KPS pada kelompok eksperimen tertinggi adalah aspek mengamati $(83,8)$. Terlihat kelompok eksperimen lebih tinggi dibandingkan kelompok kontrol. Hal ini didukung saat kegiatan belajar, siswa kelompok eksperimen melakukan kegiatan pengamatan secara langsung dengan objek yang nyata, tiap siswa dalam kelompok mengamati objek pengamatan saat percobaan dilakukan. Siswa dituntut selalu aktif saat melakukan pengamatan. 
Aspek KPS yang memiliki nilai rata-rata terendah pada kelompok kontrol adalah aspek merencanakan percobaan $(53,91)$. Hal ini dikarenakan saat kegiatan belajar siswa tidak diajak untuk merencanakan percobaan, sehingga aspek merencanakan percobaan memiliki nilai yang rendah. Hal ini terbukti pada saat siswa diberikan soal tes KPS tentang merencanakan percobaan pengamatan terhadap keanekaragaman 3 buah mangga (Mangivera indica), banyak dari siswa yang tidak dapat menjawab. Aspek KPS yang memiliki nilai rata-rata terendah pada kelompok eksperimen adalah aspek menarik kesimpulan $(71,3)$. Hal ini dimungkinkan karena siswa belum terbiasa dalam menyimpulkan percobaan dengan benar sehingga nilai rata-rata aspek menarik kesimpulan menjadi rendah.

Berdasarkan hasil analisis penelitian ini menunjukkan bahwa dalam pembelajaran biologi menggunakan model pembelajaran Interjoy dapat melatih siswa dalam mengembangkan KPS sehingga hakikat sains sebagai proses dan produk dalam pembelajaran biologi dapat terlaksana secara maksimal. Peningkatan terjadi karena siswa terlibat langsung dan aktif dalam proses pembelajaran. Terkait dengan hal tersebut, Rustaman (2005) menyatakan bahwa KPS yang dilatihkan kepada siswa akan membuat siswa lebih aktif dalam kegiatan belajar.

Hal-hal yang perlu diperhatikan dalam penerapan model pembelajaran Interjoy antara lain yaitu guru harus benar-benar memahami dan mengetahui unsur-unsur dalam model pembelajaran inkuiri terbimbing dan joyful learning. Guru harus bisa menciptakan pembelajaran yang dapat mengkonstruk pengetahuan siswa melalui metode ilmiah dan dapat membuat suasana pembelajaran menyenangkan sehingga perbedaan karakter siswa dalam belajar dapat terakomodasi dengan baik. Model pembelajaran inkuiri terbimbing yang diterapkan di kelompok eksperimen melatihkan KPS siswa karena di dalam kegiatan pembelajaran siswa dibiasakan dengan kegiatan dan pertanyaan yang menunjang KPS. Suasana pembelajaran di kelompok eksperimen dibuat menyenangkan dengan cara kelas dibuat bersih, menata berbagai benda di dalam kelas sesuai dengan tempatnya sehingga timbul kesan rapi dan nyaman serta pemutaran musik instrumental secara pelan membuat suasana menjadi santai pada saat siswa sedang berdiskusi. Hal tersebut membawa pengaruh yang positif terhadap KPS siswa. 


\section{Kesimpulan}

Berdasarkan hasil penelitian, dapat disimpulkan bahwa model pembelajaran Interjoy berpengaruh nyata terhadap KPS siswa kelas X SMA Negeri 2 Surakarta tahun pelajaran 2012/2013 yang meliputi aspek mengamati, mengelompokkan, merumuskan hipotesis, merencanakan percobaan, menggunakan alat dan bahan, mengkomunikasikan, dan menarik kesimpulan.

\section{Daftar Pustaka}

Amri, S. \& Ahmadi, L.K. (2010). Konstruksi Pengembangan Pembelajaran. Surabaya: Prestasi Pustaka Publisher

Ardiyanti, Y. (2011). Penggunaan LKS (Lembar Kerja Siswa) Terbuka Untuk Meningkatkan Pemahaman Konsep, Keterampilan Proses Sains (KPS) dan Berpikir Kreatif Siswa SMA pada Konsep Pencemaran Lingkungan. (Thesis). Bandung: Universitas Pendidikan Indonesia

Asmani, J.M. (2011). 7 Tips Aplikasi PAKEM (Pembelajaran Aktif, Kreatif, Efektif, dan Menyenangkan) Menciptakan Metode Pembelajaran yang Efektif dan Berkualitas. Jogjakarta: Diva Press

Carol. (2010). Guided Inquiry: School Libraries in the 21st Century. School Libraries Worldwide, 16 (1), 17-28

DePorter, B. \& Hernacki, M. (2011). Quantum Learning, Membiasakan Belajar Nyaman dan Menyenangkan. Terj. Alwiyah Abdurrahman. Bandung: Kaifa

Masnun, M. \& Sudarman. (2010). Pengaruh Penggunaan Media Musik Terhadap Minat Belajar Siswa Pada Bidang Studi Matematika. Jurnal Eduma, 2 (2), 107-113
Prayitno, B. A. (2011). Pengembangan Perangkat Pembelajaran IPA Biologi SMP Berbasis Inkuiri Terbimbing dipadu Kooperatif STAD serta Pengaruhnya terhadap Kemampuan Berpikir Tingkat Tinggi, Metakognisi, dan Keterampilan Proses Sains pada Siswa Berkemampuan Akademik Atas dan Bawah. Disertasi tidak dipublikasikan, Universitas Negeri Malang, Malang

Pujiati, I. (2008). Peningkatan Motivasi dan Ketuntasan Belajar Matematika melalui Pembelajaran Kooperatif Tipe STAD. Jurnal Ilmiah Kependidikan, 1 (1)

Rachmawati, A.B. (2012). Penerapan Strategi Pembelajaran Berbasis Joyfull Learning Pada Materi Sistem Gerak Pada Manusia Untuk Meningkatkan Hasil Belajar Biologi Siswa Kelas Viii A SMP Muhammadiyah 4 Surakarta Tahun Ajaran 2011/ 2012. Skripsi Tidak Dipublikasikan, Universitas Muhammadiyah Surakarta, Surakarta

Rusman. (2011). Model-Model Pembelajaran: Mengembangkan Profesionalisme Guru. Jakarta: Raja Grafindo Persada

Russel, L. (2011). The Accelerated Learning Fieldbook. Terj. M Irfan Zakkie. Bandung: Penerbit Nusa Media

Rustaman, N.Y. (2005). Strategi Belajar Mengajar Biologi. Malang: UNM Press

Slavin, R.E. (2008). Cooperative Learning: Teori, Riset dan Praktik. Terj. Nurulita. Bandung: Nusa Media

Trianto. (2007). Model-model Pembelajaran Inovatif Berorientasi Konstruktivistik. Jakarta: Prestasi Pustaka Publisher

Wei, C., Hung, I., Lee, L., Chen, N. (2011). A Joyful Classroom Learning System With Robot Learning Companion For Children To Learn Mathematics Multiplication. TOJET: The Turkish Online Journal of Educational Technology, 10 (2), 11-23 
Yunianto. (2008). Penerapan Variasi

Metode Pembelajaran Berbasis Joyful Learning untuk Meningkatkan Kualitas Proses dan Hasil belajar Kesetimbangan Kimia Siswa Kelas XI IA 1 SMAN 8 Surakarta. Skripsi tidak dipublikasikan. Surakarta: FKIP UNS

Yustika, W. (2011). Pengaruh Penerapan Tutor Sebaya pada Inkuiri Terbimbing terhadap Keterampilan Proses Sains Siswa. Bandung: Skripsi S1 UPI

Zehra, O. \& Nermin, B. (2009). The Effect of a Guided Inquiry Method on Pre-service Teachers' Science Teaching Self-Efficacy Beliefs. Journal of Turkish Science Education. Vol. 6, (2) 